\title{
MAMMA, TATA I PAPAS W LACIŃSKICH INSKRYPCJACH CHRZEŚCIJAŃSKICH Z RZYMU III-VI WIEKU
}

W inspirującej pod wieloma względami pracy gromadzącej wyniki badań K.R. Bradleya nad rodziną rzymską, zwłaszcza warstw niższych, znajduje się również studium dotyczące występowania terminów tata i mamma w inskrypcjach z CIL VI. Poddam analizie analogiczne dane obecne w materiale chrześcijańskim, także z Rzymu (ICUR), dodając termin papas jako bliskoznaczny poprzednim ${ }^{1}$.

W źródłach literackich mamma i tata występują rzadko. U Warrona jest to dziecięcy termin określający matkę i ojca oraz papa, jako nazwa jedzenia w języku dziecięcym², ale u Juwenalisa ten ostatni oznacza wychowawcę, opiekuna ${ }^{3}$. W Epigramach Marcjalisa znajdujemy tekst: Mammas atque tatas habet Afra, sed ipsa tatarum | Dici et mammarum maxima mamma potest ${ }^{4}$. Mamma występuje więc jako opiekunka (osobista niewolnica) nawet ludzi dorosłych. Takie przyjaźnie, specjalny status powiernicy, znamy z literatury czasów rzymskich. Byłe mamki i opiekunki stawały się zaufanymi młodych kobiet i mężczyzn, dawnych wychowanków. Działo się tak zwłaszcza w warstwach wyższych i średnich. Persjusz natomiast używa terminu mamma jako ekwiwalentu dla nutrix ${ }^{5}$, choć równie dobrze można pod tą nazwą widzieć matkę. W dodatku należy przypomnieć, iż na ogół oznaczał kobiecą pierś, co sugeruje związki semantyczne raczej z niańką ${ }^{6}$.

${ }^{1}$ CIL - Corpus Inscriptionum Latinarum, vol. VI: Inscriptiones Urbis Romae; ICUR NS Inscriptiones Christianae Urbis Romae sept. saec. antiquiores. Nova Series; K.R. Bradley, Tatae and Mammae in the Roman Family, w tegoz: Discovering the Roman Family. Studies in Roman Social History, New York - Oxford 1991, 76-102

${ }^{2}$ Por. Varro, u Nonniusa, De compendiosa doctrina, ed. Lindsay, p. 81, 3: „cum parvuli... vocent... matrem mammam, patrem tatam"

${ }^{3}$ Por. Juvenalis, Satura VI 633: „timidus praegustet pocula papas”.

${ }^{4}$ Martialis, Epigrammata I 100, 1.

${ }^{5}$ Por. Persius, Saturae III 16-18: „(...) aut cur non potius teneroque columbo l et similis regum pueris pappare minutum I poscis et iratus mammae lallare recusas”.

${ }^{6}$ Por. Plautus, Pseudolus 1261: „ubi mamma mammicula opprimitur”; Menaechmi 20: „quae mammam dabat (karmila); Pacuvius, Tragica 192: „depulsum mamma” (odłączony od piersi); 
Badania K.R. Bradleya doprowadziły do wyróżnienia 61 napisów z określeniem mamma pochodzących $\mathrm{z}$ Rzymu (inne zbiory nie były analizowane). Do artykułu dołączono jedynie aneks wykazujący 15 inskrypcji prowincjonalnych (Italia, Hiszpania, Afryka) oraz 12 napisów z określeniami mamulae. Tata to z kolei 49 napisów z Rzymu i 14 z Italii, Sardynii, Galii i Dalmacji (także 7 tatulae) 7 .

Interpretacja napisów zebranych w CIL jest utrudniona $\mathrm{z}$ racji ich wieloznaczności. Zachodzą w nich bowiem przypadki, w których mamma i tata oznaczają biologicznych rodziców i oczywiście opiekunów dzieci. Wydaje się jednak, iż odnośnik do nutritores dominuje, choć w przypadku jednej z inskrypcji określenie mamma może oznaczać babkę (avia), a w innej macochę. W obu tych przypadkach Bradley podważa jednak taką interpretację wydawców napisu, uznając wzmiankowane kobiety za nutrices. Potwierdzałoby to zamienne używanie terminów nutrix i mammula. Historyk ten utrzymuje jednak, iż nie są to pełne synonimy, gdyż nutrix to również nazwa zajęcia oraz zajmowanego stanowiska w rodzinie (familia), natomiast mamma bądź tata to terminy osobowe, zawierające większy ładunek uczuciowy, co oznaczałoby silniejszy związek psychiczny z wychowankiem i nieco wyższą (?) pozycję w rodzinie. Pochodzenie społeczne osób pełniących analizowane funkcje jest zróżnicowane, choć w obrębie warstw niższych. Mamy do czynienia z różnym statusem dzieci, którymi się opiekowali; ze zróżnicowanym statusem społecznym rodziców; wolnymi, wyzwoleńcami i niewolnikami w przypadku mammae i tatae ${ }^{8}$.

Dominujący status opiekunek, według Bradleya, to stan wolny. Trzeba jednak pamiętać, że we wszystkich przypadkach pochodzenie społeczne zostało określone hipotetycznie. W napisach, w których figurują, jest mniej więcej równy rozkład płci zmarłych dzieci. Podobnie rzecz ma się $\mathrm{z}$ ich statusem społecznym, choć nieznacznie wydaje się tu dominować stan wolny. Autor podkreśla związek opiekunek z dziećmi we wczesnym okresie ich życia (infantia), bo aż 20 napisów odnosi się do dzieci w wieku od urodzenia do 16 lat, zaś tylko 2 przypadki do dzieci starszych, w wieku 24 i 25 lat. Ogólna wymowa inskrypcji sugeruje silny ladunek uczuciowy fundatorek - opiekunek, zawarty w napisach, wyrazający rozpacz po stracie wychowanka9

W przypadku inskrypcji pogańskich $\mathrm{z}$ tatae, których jest 49 , nie ma podstawowych różnic z poprzednimi. K. R. Bradley w zasadzie nie analizuje jednak formularzy, tylko zawartość treściową napisów. Większość opiekunów jest stanu wolnego, także - jak u opiekunek - wychowankowie są mniej więcej proporcjonalnie podzieleni pod względem płci. Status dzieci jest bardziej zróż-

\footnotetext{
Varro, Sat. Menip. p. 546: „mammam lactis sugentem pascere puppum”; Lucretius, De rerum natura V 885: „puer... ubera mammarum in somnis lactantia quaeret”.

${ }^{7}$ Por. Bradley, dz. cyt., s. 77-80, 101-102. Niektóre inskrypcje zawierają oba określenia, więc ogólna ich ilość jest mniejsza niż 110.

${ }^{8}$ Por. tamże, s. $80 \mathrm{nn}$.

9 Por. tamże, s. $79-80$ i 85.
} 
nicowany, podobnie jak rodziców, wzmiankowanych obok tatae w około połowie napisów. Opiekunowie obu płci są (tam gdzie podano dane - a to tylko 6 przypadków) w wieku między 40 a 65 lat, czyli dosyć zaawansowanym ${ }^{10}$.

S. Dixon sądzi natomiast, iż mamma, tata i nutritor (educator) to terminy synonimiczne, odnoszące się do wychowawców - opiekunów (foster parents) małych dzieci. Jest dla niej oczywiste, że sytuacje z inskrypcji odnoszą się do warstw najniższych, a mammae czy tatae są niewolnikami bądź wyzwoleńcami. Należy jednak zaznaczyć, że nie analizuje ona pełnego materiału, jak czyni to Bradley. $Z$ rozróżnieniem tych terminów wiąże się przyjęcie hipotezy o wyższym statusie mammae niż nutrix, gdyż te ostatnie byłyby wyłącznie płatnymi pracownikami $^{11}$.

Inskrypcje chrześcijańskie nie były badane $\mathrm{z}$ omawianej tu perspektywy, a w jedynym większym opracowaniu zbioru ICUR NS pod względem zawartych tam danych o realiach życia rodzinnego J. Janssens uznaje terminy mamma i tata jako synonimy mater i pater nie podając uzasadnienia takiego stanowiska $^{12}$. Analizowane dane to tacińskie inskrypcje chrześcijańskie, w których występują terminy mamma, tata, papas. $\mathrm{Z}$ ogólnej liczby 14 napisów (w tym jeden określający czynność), z ICUR NS pochodzi 9, a z E. Diehla 3 oraz 2 ze zbioru Anthologia Latina, dwa uznaję za budzące wątpliwość, co do możliwości włączenia do naszego zbioru (omówię je na końcu artykułu). Jedenaście napisów dotyczy rodzin z Rzymu, a trzy z Afryki. Nasz zbiór danych dla Rzymu jest pełny (oczywiście w ramach wydanych tomów ICUR), inskrypcje spoza Rzymu pochodzą jednak $\mathrm{z}$ niepełnego, selektywnego, tematycznego zbioru E. Diehla, dotyczącego chrześcijańskiego Zachodu (brak jest przy tym pelnych zbiorów inskrypcji prowincjonalnych $)^{13}$.

W stosunku do około 30 tysięcy napisów rzymskich analizowane dane ilościowo i jakościowo są nadzwyczaj skromne, także w stosunku do inskrypcji zawierających informacje o osobach pełniących inne funkcje w rodzinie (podobnie rzecz się ma odnośnie nutritores, choć i tu mamy nieco więcej inskrypcji, a np. informacji o alumnach jest kilkadziesiąt ${ }^{14}$.

10 Por. tamże, s. 77-78, 84-85, 101-102 oraz passim.

11 Por. S. Dixon, The Roman Mother, London - Sydney 1988, 146-149; taż, The Roman Family, Baltimore - London 1992, 129, 155 i passim.

12 Por. J. Janssens, Vita e morte del cristiano negli epitaffi di Roma anteriori al sec. VII, Roma 1981, 157 i 159.

13 Por. E. Diehl, Inscriptiones Latinae Christianae Veteres, vol. 1-3, Berlin 1925-1931 (D). Poszukiwałam danych także w zbiorze inskrypcji z Watykanu (Sylloge inscriptionum christianarum veterum Musei Vaticani, ed. H. Zilliacus, vol. 1-2, Helsinki 1963) z wynikiem negatywnym, jak i w przebadanych zbiorach inskrypcji z Italii, Galii i Hiszpanii, gdzie terminy te także nie występują. Dwie wzmianki były natomiast w Anthologia Latina (Ant. Lat.), vol. II 1-3, ed. F. Buecheler, Stuttgart 1982. Edycje źródeł por. P. Testini, Archeologia cristiana, Bari 1980, 814-826.

14 Por. Janssens, dz. cyt., s. 133 i 181-184; S. Nielsen, , Alumnus”: a term of relation denoting Quasi-Adoption, „Classica et Mediaevalia” 38 (1987) 141-188; B. Stawoska, Alumni w inskrypcjach 
Posiadamy 7 inskrypcji dotyczących mamma (wraz z odmianami w pisowni), 3 - tata, 4 - papas (w tym także papa oraz jedna $z$ określoną w ten sposób czynnością). Spotykane formy zapisu to mamma (5), mama (1), mammula (1) oraz tata, papas i papa bez wariantów. Precyzyjna datacja inskrypcji nie jest możliwa (nie czyni tego zresztą większość autorów badań opartych na napisach z ICUR) ${ }^{15}$. Można przyjąć jedynie, że $z$ powodu lakoniczności treści i danych o materii napisów nie da się dokładniej datować pozycji 2 i 4 - poza ogólną sugestią pochodzenia z III-VI wieku. Wcześniejsza (ocena w oparciu o formularz) jest być może inskrypcja nr 4 (koniec III-IV wieku), pozycje 1, 6, 9, 11-14 pochodzą być może $z$ IV lub pocz. V wieku, ze względu na bogatszy formularz, elementy greckie, poziom wykonania, ale na nieprecyzyjność takich kryteriów wskazuje napis nr 8 z 2 pol. VI wieku. Dokladnie datowane na 392, 404 oraz między 578 a 582 r. są napisy $\mathrm{nr} 8,11$ i 12 .

Formularz inskrypcji jest na ogół nieco bardziej rozbudowany o dodatkowe elementy poza imionami i odbiega korzystnie od przeciętnej dla napisów chrześcijańskich. Pozycja 3 i 5 to wyjątki, zresztą napis nr 5 jest z Afryki, gdzie treści często były lakoniczne ${ }^{16}$. W tak małym zbiorze są aż dwa przypadki poezji nagrobnej (nawet $\mathrm{z}$ nawiązaniem do Wergiliusza), trzy razy wystąpilo datowanie konsularne, w czterech - znaki graficzne. Podawano także lata życia wychowawców, daty pochówków, zawołania i aklamacje. Nie ma przy tym większych różnic między napisami, w których występują kobiety, a tymi ze wzmiankami o wychowawcach.

1. Jedynymi znanymi fundatorami napisów zawierających termin mamma są matka i opiekunka (poz. 1), które dla „swego syna” ufundowały napis, oraz fundator o trzech imionach C. L. F. (taki sposób zapisu imion fundującego jest wyjątkowy, może jednak są to imiona opiekunki?), reszta fundacji jest anonimowa. Formularz 7 analizowanych napisów jest raczej prosty. Najskromniejsze to mamma $\mathrm{z}$ Rzymu (napis malowany, moze dlatego tak skromny) i mamme in pace, pochodzący z Afryki, o nie do końca jasnej przynależności do inskrypcji chrześcijańskich. Jednak rodzinne napisy z Afryki, jak wspomniałam, cechuje w pewnych regionach daleko posunięta zwięzłość, ograniczająca się w treści do zaznaczenia imienia zmarłego, daty pochowania i aklamacji. W naszym więc

chrześcijańskich z Rzymu, w: Rodzina w starożytnym Rzymie, red. J. Jundziłl, Bydgoszcz 1993, 235257 (w ICUR i u Diehla około 150 napisów).

${ }^{15}$ Czynią to natomiast np. wydawcy inskrypcji z muzeów watykańskich (Sylloge inscriptionum..., t. 2, s. 230-248), ale mieli, w przeciwieństwie do mnie, dostęp do oryginałów, a więc możliwość datowania np. na podstawie wyglądu tablic, rodzaju pisma. Natomiast nie ma większych możliwości datacji wg formularza i imion, gdyż w tym samym czasie pojawiają się róże układy tych elementów.

${ }_{16}$ Por. B. Stawoska-Jundziłl, Zróżnicowanie oraz zaniknie informacji o stosunkach rodzinnych $w$ formularzu chrześcijaniskich inskrypcji rzymskich a prowincjonalnych okresu póżnego cesarstwa rzymskiego, ,Antiquitas” 21 (1995) 174-176. 
przypadku dziwne jest tylko opuszczenie imienia zmarłej opiekunki. Pominięcie imienia osoby zmarłej występuje $w$ jeszcze jednym napisie, tym razem rzymskim, w którym jednak zawarty jest duży ładunek uczuciowy, gdyż zastosowano zdrobnienie terminu mamma do mammulae oraz określono zmarłą jako piissima i zastosowano zwyczajową, ale prestiżową aklamację bene merenti (poz. 2). Natomiast w odniesieniu do alumnów takie pominięcia są dosyć częste, co może oznaczać status niewolniczy - dla wystawców napisów liczyła się pozycja w rodzinie, a nie konkretny człowiek ${ }^{17}$. Inskrypcje zawierają pojedyncze imiona opiekunek (Donata, Trofime, Victoria), co może, ale nie musi, oznaczać ich rzymskie pochodzenie. Imię Donata wskazuje, być może, na związki $z$ donatyzmem afrykańskim.

Określenia towarzyszące mamkom - opiekunkom to powtarzające się dwukrotnie fidelis, vixit fidelis (wierna, godna zaufania, czcigodna, pobożna), związane z Afryką (por. inskrypcje w zbiorze E. Diehla), oznaczają może prawomyślność, ale także mogą sugerować właśnie wierność odłamowi donatystycznemu. Przymiotniki piissime, bene merenti, $B$. D. (bene dicta?), zwrot mamme nvtrici sve, mammvlae wskazują na bliski związek pomiędzy fundatorem a fundowanym. Bene merenti może także oznaczać chęć podkreślenia bliskiego związku z opiekunką, poczucia długu w stosunku do niej za wcześniejszą opiekę, zgodnie ze znaczeniem tego określenia ustalonym przez Hanne Nielsen w odniesieniu do napisów niechrześcijańskich $z$ Rzymu ${ }^{18}$. Brak imienia przy jednoczesnym występowaniu akcentów emocjonalnych sugeruje, że fundatorom nie zależało na podkreśleniu roli własnej osoby w takiej fundacji, ale uhonorowaniu ulubionych opiekunek. Być może jednak nie było się czym chwalić, skoro fundacje dotyczyły osób o niskim statusie społecznym, gdyż inaczej pojawilyby się imiona członków rodziny. Także zresztą pominięcie imion nianiek sugeruje pewną dehumanizację takich osób, cenionych za pełnione funkcje, a nie jako konkretne osoby.

Tylko w jednym przypadku podano wiek zmarłej jako plus minus 70 lat. Jedna $\mathrm{z}$ wielu interpretacji podanej formuły wiąże takie napisy $\mathrm{z}$ nikłym wykształceniem i niskim pochodzeniem fundatora i fundowanego, ale jest ona słusznie podważana, gdyż występuje także w stosunku do członków warstw wyższych ${ }^{19}$. Wytłumaczeniem może być także brak bliższych danych o wieku i pochodzeniu starej opiekunki u nie najmłodszych już jej wychowanków.

${ }^{17}$ Por. Stawoska, Alumni..., art. cyt., passim. Oczywiście lakoniczność treści napisu nr 3 wynikać może z uszkodzeń inskrypcji. Może oznaczać także imię.

${ }^{18}$ Por. H.S. Nielsen, Interpreting epithets in Roman epitaphs, w: The Roman Family. Status, Sentiment, Space, ed. B. Rawson - P. Weaver, Oxford 1997, 179-185. W CIL VI stosowano go najczęściej dla zmarłych między 15 a 45 rokiem życia.

${ }^{19}$ Podkresla się także tendencje do wiązania tej formuly $\mathrm{z}$ wiekiem dzieci i ludzi starszych oraz podawanie wtedy wieku cyfrą zaokrągloną, jak w tym przypadku, por. Sylloge inscriptionum..., s. 187-188. 
Towarzyszące napisom aklamacje in pace (trzy razy) mają charakter typowo religijny i zgodny $z$ formularzem napisów chrześcijańskich, gdzie występują bardzo często ${ }^{20}$. Inskrypcja rzymska (poz. 4) zawiera natomiast rzadko spotykamy końcową formułę, podaną w skrócie $\mathrm{BD}$, co może oznaczać: Beatus Dominus, ale także: bene dicta.

$\mathrm{Na}$ tle innych napisów rodzinnych omawiane inskrypcje są dosyć proste, ale i ze znacznym ładunkiem uczuciowym. Podkreśla to sytuacja, w której matka i opiekunka (mama) fundują napis ,synowi” Laurentiusowi, określanemu jako dulcissimus, zmarlemu w wieku 1 roku i 4 miesięcy. Napisowi towarzyszy podanie daty pochowania (w kalendy lutego) i aklamacja in pace. Napis cechuje nieuporządkowany formularz i złe rozplanowanie, co spowodowane zostało podyktowaniem go przez niewykształconego fundatora lub wykonaniem przez warsztat rzemieślnika o niskim poziomie wykształcenia. Tablica jest jednak marmurowa, a litery stosunkowo duz $\mathrm{e}^{21}$.

W omawianym przypadku zachodzi sytuacja, w której fundatorem jest matka (mater), która pełniła jednocześnie funkcję mamki (opiekunki) zawodowej, która zajmowała się także swoim naturalnym synem, a nie wychowankiem. Wskazuje na to głównie określenie filio suo. Może jednak również zachodzić przypadek, iż matka i opiekunka są dwiema różnymi osobami, traktującymi zmarłego chłopca jak wlasnego syna, co w przypadku mamki mogłoby świadczyć o dużym ładunku uczuć w stosunku do wychowywanego dziecka. W końcu formuła mater et mama oznaczać może, iż matka chciała podkreślić fakt samodzielnej opieki nad dzieckiem (karmienie!). Od schyłku republiki (ale zwłaszcza w I - II w. n.e.) propagowano przecież intensywnie samodzielne karmienie dzieci bez korzystania $\mathrm{z}$ usług mamek ${ }^{22}$.

Jeśli chodzi o rolę $\mathrm{w}$ rodzinie, to mamy do czynienia z matką, która określiła się jako mamma, bądź matką i opiekunką (poz. 1); opiekunką zrównaną $\mathrm{z}$ funkcją nutrix (poz. 4) oraz czterema przypadkami w których nie mamy możliwości jej bliższego określenia. Na podstawie naszego materiału nie można więc zdecydować o tym, że jest to synonim dla nazwy mater, czy też opiekunki (nutrix) oraz o jej statusie człowieka wolnego, wyzwoleńca czy niewolnika. Treści wskazują jednak, że otaczano ją w każdym przypadku cieplymi uczuciami.

${ }^{20}$ Por. Testini, dz. cyt., s. 405-440.

${ }^{21}$ Podobnie w innych napisach wystawionych dla najmłodszych dzieci, które są wyjątkowo liczne w Rzymie, w porównaniu z inskrypcjami niechrześcijańskimi w CIL VI, por. B. StawoskaJundzill, Dzieci $w$ wieku nie przekraczającym roku w tacińskich inskrypcjach chrześcijaniskich z katakumb Rzymu, w: Dziecko w rodzinie i spoteczeństwie, t. 1: Starożytność - średniowiecze, red. D. Żołądź-Strzelczyk - J. Jundzill, Bydgoszcz 2002, 188-207.

22 Por. J. Jundzill, Wzorce i modele wychowania w rodzinie rzymskiej okresu III w. p.n.e. - III w. n.e., Bydgoszcz 2001, passim. 
Status społeczno-ekonomiczny rodzin, do których należały opiekunki, można jedynie próbować określić jako lepszy od przeciętnej w przypadku inskrypcji nr 1 i 4 z Rzymu, gdyż napisy są staranniejsze, a napis nr 4 ma skromne zdobienie motywem liścia ${ }^{23}$. Natomiast teza, iż wzmianki o mammae wiążą się raczej z pochówkami małych dzieci, tu się nie potwierdza, gdyż dotyczy jednego przypadku (nr 1), pozostałe wystawiali starsi wychowankowie lub inni członkowie rodziny.

2. Posiadamy tylko dwie inskrypcje łacińskie i jedną grecko-łacińską $\mathrm{z}$ terminem tata. Pierwsza jest tak uszkodzona, iż można $\mathrm{z}$ niej jedynie wywnioskować zastosowanie wzbogaconego formularza, nawet $\mathrm{z}$ konsularną datą pochowania. W drugiej tata jest fundatorem napisu dla dziewczynki o imieniu Centia, określonej terminami anima innocentia, która zmarła w wieku 5 lat i 10 miesięcy. W napisie podano datę pochówku i aklamację dormit in pace oraz symbol wiary (chrysmon). Opiekun nie wymienił swojego imienia oraz innych danych blizej opisujących jego osobę. Mocno zaakcentował natomiast wyznawaną wiarę. Tablicę cechuje względnie wysoki poziom wykonania napisu i jego rozbudowana treść. Może to świadczyć o nieco wyższym statusie spoleczno-materialnym fundatora.

Trudno określić przyczynę ufundowania napisu przez opiekuna, a nie przez rodziców czy rodzica, o ile oczywiście nie mamy do czynienia $\mathrm{z}$ ojcem. Być może w chwili śmierci dziecka rodzice już nie żyli; jeden $\mathrm{z}$ rodziców - matka samotnie wychowywała dziecko przy pomocy opiekuna i obumarła je wcześniej. Możliwy jest również przypadek pobytu rodziców - rodzica $z$ dala od dziecka w chwili jego śmierci. Być może mamy też do czynienia $\mathrm{z}$ dzieckiem rodziców niewolnych, sprzedanym poza ich miejsce zamieszkania. Jednak jednym $\mathrm{z}$ najbardziej prawdopodobnych powodów takiej konstrukcji napisu może być przypadek określenia się $\mathrm{w}$ ten sposób przez naturalnego ojca, który używając języka dziecięcego podkreśla w ten sposób swój związek emocjonalny $z$ dzieckiem, byłby to jednak rzadki przypadek ${ }^{24}$. Podana tu, jako uzupelnienie informacji, inskrypcja grecka nie wnosi nic konkretnego do określenia pozycji w rodzinie takich osób. Wydawca sugeruje jednak wariant interpretacyjny oznaczający ojca.

Nie jest też jasne, dlaczego użyto terminu lacińskiego w napisie greckim (nr. 10), może wychowawca był Grekiem należącym do rodziny Rzymian.

\footnotetext{
${ }^{23}$ W tym przypadku liście pełnią rolę zdobniczą, tworzą ramy napisu, mogą mieć jednak także znaczenie symboliczne, por. Sylloge inscriptionum..., t. 2, s. 100-102.

${ }^{24}$ Uczucia do dzieci były jednak manifestowane zarówno w napisach z CIL, jak i ICUR (materiał chrześcijaŕski odnoszący się do dzieci w wieku 0-7 lat analizuję w rozprawie przygotowywanej do druku), por. G. Nathan, The Family in Late Antiquity, London - New York 2000, 133$138,142-155$.
} 
3. Dwie inskrypcje zawierają termin papas; trzecia, o trudnej do zrozumienia treści, zawiera termin papa oraz jedna określenie umowne nawiązujące do naszego papas za pośrednictwem określenia wykonywanej czynności: papatem. W obu przypadkach, gdzie użyto terminu papas wprost połączono go z określeniem nutritor. Napisy mają też podane imię opiekuna: Antimius, Crispius, Felix, Iovinianus, są to więc Rzymianie wolni lub wyzwoleńcy, ale mogli być też niewolnikami. W napisach nie określono fundatorów, rozbudowane natomiast zostały treści inskrypcji. W odniesieniu do inskrypcji z pozycji 12 można przypuszczać, iż fundatorami byli trzej wychowankowie będący braćmi.

W dwu przypadkach dysponujemy datowaniem, przez podanie imion konsulów, na lata 392 i 404 rok. Dwa razy określono wiek opiekunów jako: pm XL i LXX. Podanie okrągłych cyfr, a w pierwszym przypadku użycie formuły plus minus (pm), wskazuje prawdopodobnie, iż fundatorami byli jednak wychowankowie, a nie ich rodzice, którzy mogliby bliżej określić wiek opiekunów. Za tą tezą przemawia również dość zaawansowany wiek pochowanych - 40 i 70 lat.

Opiekun 40-letni wyposażony został $\mathrm{w}$ epitet bene merenti oraz in pace, czyli o wyróżnieniu świadczy data konsularna, podanie wieku oraz symbol gołębia (odnieść go można do pozytywnych cech charakteru zmarłego oraz wyznawanej wiary wychowanków i opiekuna), a nie rozbudowana treść. Natomiast 70-letniemu Antimiusowi poświęcono stosunkowo krótki tekst, ale o dużym ładunku treści religijnych, co wcale nie jest takie częste w inskrypcjach $\mathrm{z}$ Rzymu. W dodatku położono nacisk na szczęśliwość życia wiecznego, czy można interpretować to jako aluzję do kłopotów wychowawcy-niewolnika, nie wiadomo.

W innym przypadku (nr 14) mamy sytuację przeciwną. Pochwałom wiary towarzyszy podkreślenie doczesnych osiągnięć: ,szczęśliwe swoje życie głównie podporządkował chrześcijańskim prawom godnie ich strzegąc, błogosławiony (zmarły) był przyjacielem wielu, rzetelnym, zawsze wielkiej wiedzy, której udzielał (podopiecznym), opuścił Brixie i umarł (w Rzymie), jego imię Crispius". Jeśli chodziloby o wychowawcę jego pozycja byłaby nadzwyczaj wysoka. Sądzę jednak, że napis dotyczy jakiegoś zasłużonego obywatela Brixia, a nie opiekuna dzieci.

Trudno ustalić przyczynę zastosowania w tym napisie poezji nagrobnej. Zresztą, stosowano ją nie tylko dla znaczniejszych członków społeczności, ale nawet np. dla małych dzieci. Nic nie wskazuje na wyższą pozycję społeczną wychowawców. Teksty są jednak rozwinięte treściowo, a poziom techniczny ich wykonania jest odpowiednio wysoki. Należy więc przyjąć, że to bardziej świadectwo postawy wychowanków, którzy poświęcili czas i pieniądze, aby upamiętnić swych wychowawców, chcąc może własnymi tworami poetyckimi dać wyraz swym możliwościom, a nie bezpośredni dowód na wyższy status społeczny. Byli oni wychowawcami, podobnie jak mammae obdarzani silniejszymi uczuciami, niż przejawiane w stosunku do innych wychowawców. 
Odnośnie napisu nr 13 można tylko podkreślić chęć fundatora zaakcentowania wyznawanej przez niego i wychowawcę wiary poprzez stosunkowo rzadko stosowany znak krzyża. Przypadki wątpliwe, to uszkodzony tekst zawierający termin papa, ale może być to końcówka wielu innych wyrazów, w tym imienia. W drugim kamieniarz najpierw wykuł słowo tata, a później dodał $i$ tworząc imię Tatia. Może to jedynie wskazywać na stosowanie tego słowa z języka dziecięcego na tyle często, że kamieniarz mógł się dopuścić takiej pomyłki.

Inskrypcje pogańskie i chrześcijańskie z mamma, tata i papas są do siebie podobne $\mathrm{i} w$ zasadzie dotyczą podobnych sytuacji $\mathrm{z}$ tym, że $\mathrm{z}$ racji mniejszej ilości inskrypcji chrześcijańskich zawierają one mniejszy ladunek informacji o życiu rodzinnym. W obu przypadkach mamy do czynienia $z$ wychowawcami-opiekunami, lub rzadziej, rodzicami używającymi ze względów emocjonalnych języka dziecinnych zdrobnień. Wartość poznawcza analizowanych tekstów leży więc głównie w stwierdzeniu braku różnic w realiach życia rodzinnego w rodzinach niechrześcijańskich i „chrześcijańskich” ${ }^{25}$. Dalej, jak widać, potrzebna była instytucja specjalnych opiekunów do dzieci w ciągle jeszcze licznej familia i do dzieci wolnych. Możliwa jest też konstatacja inna: naturalni rodzice nie wstydzili się przyznawać językiem dziecięcym do rozpaczy po stracie dzieci, to samo czynią wychowankowie. Działo się tak przecież w wielu fundacjach rodzinnych w Rzymie, choć szerzej dopiero w IV wieku ${ }^{26}$.

Potwierdza się też teza Bradleya o specjalnym wyróżnianiu tego rodzaju opiekunów spośród grupy nutritores. Zastanawiający jest brak imion fundatorów, ale w ICUR mamy do czynienia ze znacznym zróżnicowaniem formularzy, od zupełnie oschłych po poezję nagrobną. Sądzę jednak, że i w przypadku chrześcijan ważniejsze było uznanie wagi pełnienia funkcji przez opiekunów, traktowanych z czułością, ale nie dlatego że reprezentowali takie czy inne cechy jako jednostki, tylko za wykonywane w przeszłości obowiązki czułych rodziców

${ }^{25}$ Cudzysłów oznacza, iż uważam za wysoce uproszczoną ocenę, spotykaną w literaturze naukowej, egzystencji rodzinnej, deklarujących wiarę chrześcijańską (choćby poprzez pochówek w katakumbach i cechy napisów), jako bytowanie w rodzinie chrześcijańskiej. Obserwujemy w źródłach pisanych i inskrypcjach zbyt duże naleciałosci obyczajów i ideologii klasycznej w życiu rodzinnym chrześcijan. Rodziną chrześcijańską jest natomiast z pewnością grupa żyjąca w klasztorze lub, wg tego wzoru, w otoczeniu świeckim.

26 Por. B. Stawoska-Jundziłl, Relacje rodzice - dzieci od 14 roku życia $w$ datowanych inskrypcjach nagrobnych miasta Rzymu, w: Wychowanie w rodzinie od starożytności po wiek XX, red. J. Jundziłł, Bydgoszcz 1994, 113-128, Nielsen, Interpreting Epithets in Roman Epitaphs..., dz. cyt., s. 169-204. 
zastępczych, dostarczycieli ciepła, którego dzieci nie otrzymały w wystarczającej ilości od rodziców.

Podstawową różnicą jest o wiele mniejsza ilość napisów chrześcijańskich w stosunku do pogańskich. Można założyć, iż „społeczność katakumb" była biedniejsza od tej reprezentowanej w CIL VI, ale i tam przeważały napisy $\mathrm{z}$ warstw niższych. Być może więc chodzi o zastosowanie w praktyce ideału z okresu klasycznego, samodzielnego karmienia i wychowywania małych dzieci? Do takiego stanowiska przychyla się G. Nathan, ale i on przytacza w tym przypadku raczej nawoływania Ojców Kościola, aby samodzielnie wychowywać dzieci, co świadczy o dominacji sytuacji odwrotnej, skoro potrzebne były apele. Czy zatem obecność nianiek była i w przypadku chrześcijan dość powszechna, w każdym razie świadectwa o nich zanikają od $\mathrm{V}$ wieku ${ }^{27}$.

Napisów dla małych dzieci jest stosunkowo dużo, więcej niż w CIL VI; wiele $\mathrm{z}$ nich wystawiali rodzice, ale część nie ma określonych fundatorów. Być może niektóre $\mathrm{z}$ nich fundowali opiekunowie, tacy jak tu opisywani. Charakterystyczna jest też niechęć chrześcijan do częstszego podawania informacji o karierze w życiu doczesnym, stąd tylko niewiele inskrypcji zawiera dane np. o pełnionych zawodach. Na podstawie analizowanego materiału można więc tylko postawić hipotezę o zmniejszaniu się roli nutritores $\mathrm{w}$ rodzinach chrześcijan. Ci jednak, którzy wyróżnili się w jakiś sposób, pozyskiwali u swych wychowanków bardzo cieple uczucia i długoletnie przywiązanie symbolizowane także specjalną terminologią odnoszącą się do ich zajęć i pozycji w rodzinie.

\title{
MAMMA, TATA AND PAPAS IN CHRISTIAN LATIN INSCRIPTIONS FROM ROME OF III-VI CENTURIES
}

\author{
(Summary)
}

The article is an analysis of the Christian inscriptions from Roman catacombs (ICUR NS vol. 1-10), which include words: mamma, tata, papas and their derivatives. In comparison to non-Christian inscriptions from CIL, investigated by K.R. Bradley (129 from Rome and 29 from provinces), Christian ones are not numerous, as we have 14 of them and 2 which are doubtful. They originate from the whole period of exhibition of Christian epitaphs in Rome, which lasted from III to VI century. The discussed words most frequently are related to nannies and a man, who looked after infants and little children - the same situation took place in pagan societies. Those people stayed with the families till the end of their lives. Just like in the pagan

${ }^{27}$ G. Nathan, op. cit., s. $150-154$ 
societies, it has been stated that the tutors had contacts with grown up wards, though the feelings were usually caused by the actions performed not by preceptors themselves. The inscriptions often does not include the names of those people. Also the tutor have some strong feelings towards the children as they happened to found some epitaphs themselves. Only some of inscriptions may prove using the words discussed in relations to parents. Few inscriptions may indicate the will of resigning of the preceptors' services and taking the tasks over by children's parents. That may be also caused by economical problems of the family burying the dead members in the catacombs. 


\section{ANEKS ZE SPISEM ŹRÓDEŁ}

(Pisownia według edytorów źródeł, w przypadku zachowania inskrypcji w odpisie brak danych o wymiarach tablic i liter; kolejność wg numerów ICUR i D)

1. MATER - ET MA $\cdot$ MA $\cdot$ FECIT $\cdot D P$.

FILIO SVO D DULCISIMO - VIIX .

QVI BIXIT ANNO $\cdot 1 \cdot$ ET $\cdot$ CA LENDAS FEBRI

$$
\text { MESES - IIII - LAVRENTI IN PACE }
$$

(ICUR 4. 11935, tab. marmurowa $20 \times 65 \mathrm{~cm}$, litery $2.5 \sim 3 \mathrm{~cm}$ )

2. MAMMVLAE

PIISSIME BE

NE MERENTI

(ICUR 7. 19642, odpis)

3. MAMMA

(ICUR $8.21168 \mathrm{~b}$, napis malowany, litery $4 \mathrm{~cm}$ )

4. TROFIMENI C C.L.F

$\checkmark M A M \cdot M E \curvearrowright N V T R I C I$

$S V E \sim$ FECIT

- B . D .

(ICUR 9. 24768 tab. marmurowa $38 \times 165 \mathrm{~cm}$, litery $2 \sim 3 \mathrm{~cm}$, czerwone)

5. Mamme

in pace

(D 2520 A adn.; CIL 8. 21425 Afryka [pogańska?])

6. mamma Donata uixit fide

lis in pace annos plu

$s$ minus Septuaginta

(D 1394 B; CIL 8. 23060, Afryka, okolice Hadrumentum)

7. Victo

ria fidel

is mamma

in pace

(D 1397; CIL 8. 27 696, Afryka, Sicca [wg Bradleya pogańska?]) 
8.

$$
\begin{aligned}
& \text { "I } \\
& \text { QVANTI } \\
& \text { TATA. EST } \\
& \text { T PACEM EEI }
\end{aligned}
$$

hi] C REQVIESCIT BEI

C XII IMP TIBER II Clonstantini...

(ICUR 2. 4188, odpis, między 578 a 582 r., u góry oznaczenie grobu [?])
9. TATA CENTIAE ANIME INNOCENTI QVE VIXIT ANNIS chrismon QVINQVE MENSES X DORMIT IN PACE VI KAL. IEN

(ICUR 3. 8924, odpis)

10. $\Theta A P C I$ TATA MHTHP OY $\triangle E I C A \Theta A H A$ TOC

(ICUR 7. 19844 tab. brak innych danych)

11. Perpetuam sedem nutritor possides ipse hic meritus finem, magnis defuncte periclis, hic requiem felix sumis cogentibus annis.

Hic positus papas Antimio, qui uixit annis $L X X$, Depositus domino nostro Arcadio II et Fl. Rufino cc ss. nonas Nobembr (D 754; Ant. Lat. II. 1, 675, Rzym, w. 2: Verg., Aen. VI. 83)

12. hic iacet louinianus nutritor et papas trium fratrum, depositus pridie idus augustas

Honorio Aug. VI benemerenti in pace uixit nnos pllus) $m$ (inus) $X L$ (gołąb $\mathrm{z}$ uszkodzoną głową) (ICUR 10. 27332 (= D 755), kursywą fragmenty widziane przez wydawców, tab. marmurowa $58.3 \times 185 \mathrm{~cm}$, litery $5.5 \sim 11.5 \mathrm{~cm}, 404$ rok)

13. FEELIX VII $\triangle \mathrm{PL} \Lambda$ NIICISIIO DVI 1

OIN AQ $\cdot$ DI $\cdot$ ORVT PAPA NONIS DECIIS

(ICUR 1. 364, odpis)

14. Felix uita sua quondam dum forte ma neret cristianeque legis cultor mer $[\mathrm{t}] \mathrm{o}[\mathrm{q}] \mathrm{ue}$ beatus, amicum mul[ $t]$ is $[f]$ ides que $(\mathrm{m})$ maxi ma semper Iflecerat et modus sapientia que papatem, Brixiaque domo et [f]uit cui 
500

BOZENA STAWOSKA-JUNDZILE

Crispio nomen.

(D 1591 A; Ant. Lat. II. 3, 2191, Rzym, w. 1: Verg., Aen. V. 724)

Wątpliwe:

1. ...PAPA

(ICUR 1.770, odpis)

2. TATI $\triangle$ ARISTE

ARISTE

(ICUR 3. 9177, odpis XVIII w.) 